\title{
Trafficking of Human Beings for the Purpose of Organ Removal: Are (International) Legal Instruments Effective Measures to Eradicate the Practice?
}

\author{
Alexis A. Aronowitz ${ }^{1}$
}

Elif Isitman ${ }^{2}$

DOI: $10.21827 / 5 a 86 a 79483992$

\begin{abstract}
Keywords
ORGAN TRAFFICKING, ILLEGAL ORGAN TRADE, HUMAN TRAFFICKING, ORGAN DONORS, ORGAN RECIPIENTS, ORGAN DONATIONS, PRESUMED CONSENT, LEGAL INSTRUMENTS, INTERNATIONAL LEGISLATION, SUPRANATIONAL LEGISLATION, DOMESTIC LEGISLATION, EXTRA-LEGAL MEASURES.
\end{abstract}

\begin{abstract}
Organ trafficking is perhaps the most obscure form of human trafficking. It is an international problem with transnational dimensions and involves the intersection between the world of organized crime, impoverished organ donors, sick recipients and unscrupulous medical staff. This article starts out by exploring the global patterns of organ trafficking, highlighting the physical and psychological harm caused to victims. The statistics on organ transplants and patterns of organ trafficking as well as the social, economic and legal dimensions of this type of crime are examined. The article subsequently continues with a discussion of the domestic, regional and international legal and semi-legal instruments established to battle organ trafficking and reflects upon whether or not these instruments are effective in curtailing this growing problem. The article ends with a discussion of alternative approaches to deal with the problem of organ trafficking and makes a case for more problem-driven solutions, such as increased extra-legal measures, international cooperation and a focus upon the causes and victims of organ trafficking rather than focusing upon criminal law alone.
\end{abstract}

\section{Introduction}

Organ trafficking is perhaps the least understood and investigated form of human trafficking. It is a growing international problem with transnational dimensions. Organ trafficking involves the intersection between the criminal world of traffickers,

Alexis A. Aronowitz is a Senior Lecturer in Criminology and an Academic Advisor at University College Utrecht, the Netherlands and works as an independent consultant on human trafficking. She has served since 2000 as a research expert and consultant on projects in the field of trafficking in human beings for a number of United Nations organizations, the International Organization for Migration, the Organization for Security and Cooperation in Europe and other international organizations. She is the author/coauthor of several reports for these organizations as well as numerous journal articles, book chapters and a book on the subject.

2 Elif Isitman received her MSc in International Crimes and Criminology and an MA in Journalism from the Vrije Universiteit Amsterdam. Her MSc dissertation concerned the trafficking of women and girls in post-conflict areas, using Bosnia \& Herzegovina and Kosovo as case studies. Following her MSc studies, she interned and worked at the Bureau of the Dutch National Rapporteur on Trafficking in Human Beings and Sexual Violence against Children (BNRM), where she conducted research into child pornography and corresponding perpetrator profiles. 
impoverished donors, sick recipients and unscrupulous medical staff. This article explores the dimensions of organ trafficking, global patterns and physical and psychological harm to victims. It concludes with a discussion of domestic and international instruments used to regulate the trade in organs, and examines whether or not legal instruments can be effective in regulating and controlling this trade.

\section{Human Trafficking}

On 25 December 2003 the United Nations Protocol to Prevent, Suppress and Punish Trafficking in Persons, Especially Women and Children, supplementing the United Nations Convention against Transnational Organized Crime, entered into force. ${ }^{3}$ Human trafficking, according to Article 3 of the Protocol, is defined as:

[...] the recruitment, transportation, transfer, harboring or receipt of persons, by means of the threat or use of force or other forms of coercion, of abduction, of fraud, of deception, of the abuse of power or of a position of vulnerability or of the giving or receiving of payments or benefits to achieve the consent of a person having control over another person, for the purpose of exploitation. Exploitation shall include, at a minimum, the exploitation of the prostitution of others or other forms of sexual exploitation, forced labor or services, slavery or practices similar to slavery, servitude or the removal of organs. ${ }^{4}$

For an act to be considered human trafficking, it must comprise the three constituent elements and one element from each must be present for trafficking to occur: (1) an action (recruitment, transportation, transfer, harbouring or reception of persons); (2) through means of (threat or use of force, coercion, abduction, fraud, deception, abuse of power or vulnerability, or giving payments or benefits to a person in control of the victim); and (3) goals (for exploitation or the purpose of exploitation which includes exploiting the prostitution of others, other forms of sexual exploitation, forced labour or services, slavery or similar practices, and the removal of organs).

Based upon Article 3 of the UN Trafficking Protocol, the Declaration of Istanbul on Organ Trafficking and Transplant Tourism defines organ trafficking as the:

[...] the recruitment, transport, transfer, harboring or receipt of living or deceased persons or their organs by means of the threat or use of force or other forms of coercion, of abduction, of fraud, of deception, of the abuse of power or of a position of vulnerability, or of the giving to, or the receiving by, a third party of payments or benefits to achieve the transfer of control over the potential donor, for the purpose of exploitation by the removal of organs for transplantation. ${ }^{5}$ The discussion around the phenomenon is not about the trafficking of organs

3 GA Resolution $39574\left(55^{\text {th }}\right)$ of 15 November 2000, Protocol to Prevent, Suppress and Punish Trafficking in Persons, Especially Women and Children, Supplementing the United Nations Convention Against Transnational Organized Crime, 2237 UNTS 319; Doc. A/55/383, available online at <treaties.un.org/Pages/ViewDetails.aspx?src=TREATY\&mtdsg_no=XVIII-12a\&chapter=18\&lang=en $>$ (accessed 5 June 2013. As of June 2013 it has been ratified by 155 states.

Ibid.

5 Declaration of Istanbul on Organ Trafficking and Transplant Tourism, World Health Organization, 2008 , available online at $<$ declarationofistanbul.org/index.php?option=com_content\&view $=$ article\&id=81\&Itemid=85> (accessed 12 October 2013). 
per se, but the trafficking of human beings for the purpose of organ removal.

One must understand organ trafficking within the context of transplant commercialism and transplant tourism. Both involve the commodification of the human organ (often a kidney or liver) which is bought or sold for commercial or material gain. While travel for transplantation - the movement of donor, recipient or transplant professionals across jurisdictional borders - may be legitimate, the practice becomes transplant tourism when the practice "...involves organ trafficking and/or transplant commercialism or if the resources (organs, professionals, and transplant centers) devoted to providing transplants to patients from outside a country undermine the country's ability to provide transplant services for its own population." 6 Transplant tourism has often been linked to organ trafficking.

\section{Organ Trafficking}

\section{III.1. Background}

Organ trafficking is perhaps the least profiled and understood form of human trafficking. It often involves the intersection of donor, recipient, medical experts and (organized) criminal groups facilitating the trade. While the United Nations Office on Drugs and Crime ${ }^{7}$ and the Council of Europe ${ }^{8}$ also refer to the trafficking in organs or tissues (often from cadaver donors), the focus of this paper will be on the trafficking of live human beings for the purpose of organ removal.

In 2006, the United Nations came to the conclusion that it was impossible to provide any estimation on the scope of organ trafficking. ${ }^{9}$ The topic was not a priority nor had it received close scrutiny in Member States. Most cases included in the report involved the illegal removal and trafficking of organs or tissue from deceased persons. $^{10}$ A year later, however, at the Second Global Consultation on Human Transplantation of the World Health Organization (WHO) in March 2007, it was estimated that "...the extent of organ sales from commercial living donors (CLDs) or vendors has now become evident..." and was estimated at $5-10 \%$ of the annual kidney transplants performed around the world. ${ }^{11}$

The improvement of health care in many parts of the developed world has contributed to an increased life expectancy, resulting in a larger population of older people. At the same time, technological and medical developments have facilitated the

6 Ibid. Also, the full declaration can be found in Clinical Journal of the American Society of Nephrology, vol. 3 , no. 5 , 2008, 1227-1231, (128).

7 United Nations Office on Drugs and Crime (UNODC), Toolkit to Combat Trafficking in Persons, 2008, available online at <unodc.org/documents/human-trafficking/HT_Toolkit08_English.pdf> (accessed 14 July 2013)

8 Council of Europe. Trafficking in organs, tissues and cells and trafficking in human beings for the purpose of the removal of organs, 2009, available online at coe.int/t/dghl/monitoring/trafficking/docs/news/organtrafficking_study.pdf $>$ (accessed 14 July 2013).

9 United Nations, Report of the Secretary-General, Preventing, combating and punishing trafficking in human organs, Vienna, February 21, 2006, available online at $<$ www.unodc.org/unodc/en/commissions/CCPCJ/session/15.html> (accessed 27 November 2013).

10 Ibid.

11 Budiani-Saberi, D. A. and Delmonico, F. L., "Organ Trafficking and Transplant Tourism: A Commentary on the Global Realities", American Journal of Transplantation, vol. 8, ed. 5, 2008, 925929, 925 . 
transplantation of organs, making this an almost routine procedure. The demand for organs far exceeds the supply and the shortage is acute. Between 1990 and 2003, kidney donations in the United States increased only 33\%, but those awaiting a kidney for transplant increased by $236 \% .{ }^{12}$ According to the United States Department for Health and Human Services, there were, as of 5 June 2013, 118,226 candidates waiting for organs (75,643 of whom are active waiting list candidates), but only 3,412 donors registered in the U.S. as of March that year..$^{13}$ Data on organ transplants from the WHO shows that of the 106,879 organs known to have been transplanted in ninety five Member States in 2010, slightly more than two thirds (68.5\%) were kidneys. But those 106,879 operations satisfied only $10 \%$ of the global need, according to the WHO. ${ }^{14}$

The wait for a kidney in the U.S. in 2008 was twenty one days to eight and a half years. ${ }^{15}$ This problem has been identified elsewhere as well. The chronic shortage in Europe means between $15 \%$ and $30 \%$ of European patients will die while waiting for a kidney transplant, which averages about three years. ${ }^{16}$ The US Department of Health and Human Services estimates eighteen people in the U.S. will die each day waiting for an organ. ${ }^{17}$

Organs can be obtained from living or deceased donors. Waiting times for an organ from a cadaver, usually a kidney, differs from one country to the next. This ranges from an average wait in Britain and the United States of two to three years, to six to eight years in Singapore, and a longer wait in the Gulf States and Asia. ${ }^{18}$ The shortage in organs from cadaver donors has been driven, in part, by religious beliefs that the body should be buried intact, and to a fear of hospitals intentionally allowing patients to die in order to harvest their organs for paying patients. ${ }^{19}$ A shortage in cadaver organs and lengthy waiting times for organ transplant has led many in need of a kidney to seek to obtain one from a live donor. ${ }^{20}$

There are a number of reasons that a person seeking an organ prefers one from a live donor. According to the International Association of Living Organ Donors, the quality of organs from live donors "tends to be superior to organs from deceased donors". ${ }^{21}$ The European Directorate for Quality of Medicines and Health Care

12 United Nations Global Initiative to Fight Human Trafficking (UN.GIFT), "011 Workshop: Human Trafficking for the Removal of Organs and Body Parts", 13-15 February 2008 Background Paper, Vienna, available online at <www.ungift.org/doc/knowledgehub/resourcecentre/GIFT_ViennaForum_HumanTraffickingfortheRemovalofOrgans.pdf $>\quad$ (accessed 27 November 2013), citing Scheper-Hughes, N., 'Illegal Organ Trade: Global Justice and the Traffic in Human Organs' (forthcoming).

13 US Department of Health and Human Services, Organ Procurement and Transplantation Network, available online at <optn.transplant.hrsa.gov> (accessed 5 June 2013).

14 The Guardian, Campbell, D. and Davison, N., Illegal kidney trade booms as new organ is 'sold every hour', 27 May 2012, available online at <guardian.co.uk/world/2012/may/27/kidney-tradeillegal-operations-who> (accessed on5 June 2013).

15 Budiani-Saberi, D.A. and Delmonico, F.L., supra, nt. 11, 925-929.

16 Council of Europe, Trafficking in Organs, Parliamentary Assembly, 3 June 2003, available online at <assembly.coe.int/documents/workingdocs/doc03/edoc9822.htm> (accessed 12 October).

17 US Department of Health and Human Services, available online at <organdonor.gov/index.html> (accessed 5 June 2013).

18 Rothman, D. and Rothman, S., "The Organ Market", The New York Review of Books, Vol. 50, ed. 16, 23 October 2003, available online at http://www.nybooks.com/articles/archives/2003/oct/23/theorgan-market/ (accessed 27 November 2013).

19 Aronowitz, A.A., Human Trafficking, Human Misery: The Global Trade in Human Beings, Greenwood Publishing Group, 2009.

20 Rothman, D. and Rothman, S., supra nt. 18.

21 See International Association of Living Organ Donors, Inc. at http://www.livingdonorsonline.org/kidney/kidney2.htm. 
emphasises the fact that organs from living donors are more desirable as surgeries can be planned in advance, patients can be prepped with pre-operative treatment ${ }^{22}$ and that "long-term survival is usually better, due to a much shorter ischaemic time and a superior physiological state of the transplanted organ". ${ }^{23}$

Recipients also have a decreased likelihood of rejection of the transplanted organ. According to the International Association of Organ Donors, the United Network on Organ Sharing (UNOS) data for kidney transplants in the U.S. from 1996 to 2006, kidney graft survival rates are higher for recipients who have received organs from living donors. ${ }^{24}$ After five years, the survival rate is $68 \%$ from deceased donors and $81 \%$ from living donors; after a ten year period, the survival rate is $42 \%$ for those whose kidney has been grafted from a deceased donor, compared to a $58 \%$ survival rate for those receiving an organ from a living donor. ${ }^{25}$ It is for this reason that recipients prefer to have transplants from live donors.

\section{III.2. Patterns of Organ Trafficking}

Organs harvested from deceased donors are packed on ice and can be transported around the world. On the other hand, the harvesting of organs from live donors may involve the travel of both donor and recipient (and possibly the transplant experts) to the place where the transplant will occur. One of the world's leading experts on human trafficking for organ transplant, Dr. Nancy Scheper-Hughes, describes it as a trade that can bring together parties from three or more countries - the donors and recipients often come from different countries while the transplantation may occur in yet a third country. While donor and recipient may originate in the same country, transplant tourism involves the travel of donors and recipients. Shimazono (2007) introduces four modes of transplant tourism during which organ trafficking may occur. These involve situations in which the donor travels to the recipient's country, the recipient travels to the donor's country, a donor and recipient from the same country travel to a third country where the transplant centre is located, and a situation where a donor and recipient travel from different countries to a third country for the transplant procedure. The transnational nature of this crime raises questions about the possibility of its control through international law or instruments.

Historically, certain patterns have been observed. In the 1990's most recipients of kidneys were residents of the Gulf States who traveled to India to purchase an organ or they were Asians who traveled to China or India. India remains a popular destination for both purchase and transplant, ${ }^{26}$ and buyers come from India's middle class and from around the world and include the United States, Canada, England and the countries in the Middle East. ${ }^{27}$ The market has expanded, but general patterns can be observed. The trade in kidneys from live donors generally flows from poor,

22 In the case of legal transplants, both donor and recipient would be prepped and provided with care. In the case of illicit transplants, it is often only the donor who is provided with pre-operative care.

23 Council of Europe, European Directorate for Quality of Medicines and Health Care, available online at < http://www.edqm.eu/en/living-donation-1523.html> (accessed 5 June 2013).

24 Also supported by Naderi, G.H., e.a., "Living or deceased donor kidney transplantation: a comparison of results and survival rates among Iranian patients", Transplant Proceedings, vol. 41, ed. 7, 2009, 2772-2774.

25 International Association of Living Organ Donors Inc., available online at $<$ livingdonorsonline.org/kidney/kidney2.htm> (accessed 5 June 2013).

26 At the time of writing this article, the lead author was told by experts on organ trafficking in Nepal, that a particular hospital in India is being used for the transplant of organs from trafficked Nepali victims.

27 Rothman, D., and Rothman, S., supra, nt. 20. 
underdeveloped countries to rich, developed ones. There are organ-donor and organrecipient nations. ${ }^{28}$ Common countries of origin for those selling kidneys are Bolivia, Brazil, China, Columbia, Egypt, India, Iran, Iraq, Israel, Moldova, Nigeria, Pakistan, Peru, the Philippines, Romania and Turkey. Countries of origin for those purchasing kidneys are Australia, Canada, Hong Kong, Israel, Italy, Japan, Malaysia, Oman, Saudi Arabia, South Korea, Taiwan and the United States. ${ }^{29}$

\section{III.3. The donors and recipients in the organ trafficking trade}

There are about 6,000 international kidney transactions a year. ${ }^{30}$ Donors and recipients vary from one country to the next and even between regions within particular countries. There are, however, some very general trends. Organs are supplied by desperately poor people in poor countries to recipients in more affluent ones. Donors are generally minorities, and recipients of the organs - white or Middle Eastern. While donors may be male or female, most recipients of purchased organs are male, rarely female. Donors are young; recipients generally older. ${ }^{31}$

Few empirical studies exist on organ trafficking. Research in Nepal indicates that the trafficking of human beings for the purpose of organ removal occurs predominantly in one district (Kavree). Donors are young men between the ages of eighteen and forty two (average age is thirty). They come from different ethnic minority groups in the district and are extremely poor. ${ }^{32}$ In the state of Tamil Nadu, India, $71 \%$ of the 305 respondents in a study of kidney sellers were women. Almost all of the men and $60 \%$ of the women were labourers or street venders. Two of the participants reported that they were forced to sell a kidney by their husband. ${ }^{33}$ Other studies have also found that many organ sellers in India are women, however in the State of Punjab, India, it is generally poor young men (labourers) between the age of eighteen and thirty who agree to sell a kidney. ${ }^{34} \mathrm{~A}$ kidney is sometimes sold to pay the dowry for a daughter's wedding.

In Moldova, kidney sellers are poor young men from rural areas between the ages of eighteen and twenty eight, most of whom were deceived or coerced in selling their kidney. While they were paid between $\$ 2,500$ and $\$ 3,000$ to forfeit their kidney,

28 Scheper-Hughes, N., "Parts unknown. Undercover ethnography of the organs-trafficking underworld", Ethnography, vol. 5, ed. 2, 2004, 29-73.

29 Information taken from Scheper-Hughes, N., "Organs Without Borders. A new comparative advantage? Why the poor are selling their organs", Foreign Policy, ed. 146, 2005, p. 26-27, available online at <foreignpolicy.com/articles/2005/01/05/organs_without_borders> and modified with data from Saletan, W., "The Organ Market", The Washington Post, April 15, 2007, available online at <washingtonpost.com/wp-dyn/content/article/2007/04/13/AR2007041302066_pf.html> and Shimazono, Y., "The state of the international organ trade: a provisional picture based on integration of available information", Bulletin of the World Health Organization, vol. 85, ed. 12, December 2007, 955-962, available online at <who.int/bulletin/volumes/85/12/06-039370.pdf> (all accessed 13 October 2013). Published in table-format in Aronowitz (2009).

30 Information based on the World Health Organization estimates from Saletan, W., 2007, supra, nt. 29.

31 Aronowitz 2009, supra nt. 19.

32 Personal Interview by author with Dr. Meena Poudel, Anti-Trafficking, Gender and Violence Against Women Advisor, USAID, Kathmandu, Nepal, April 25, 2013.

33 Goyal, M., et al, "Economic and Health Consequences of Selling a Kidney in India", Journal of the American Medical Association, vol. 288, ed. 13, 2002, 1589-1593.

34 Deutsche Gesellschaft für Technische Zusammenarbeit (GTZ) GmbH, Pearson, E., "Coercion in the Kidney Trade? A background study on trafficking in human organs worldwide", Eschborn, April 2004, available online at <www.giz.de/Themen/en/dokumente/en-organ-trafficking-2004.pdf> (accessed 12 October 2013). 
recipients were required to pay between $\$ 100,000$ and $\$ 200,000$ for the operation. ${ }^{35}$ In Nigeria, kidney sellers are usually poor, single women. ${ }^{36}$

Table 1 Demographic Data on Organ Sellers in Different Countries ${ }^{37}$

\begin{tabular}{|c|c|c|c|c|c|}
\hline Country (State) & Gender & Age & Education & Occupation & Income \\
\hline $\begin{array}{ll}\text { India } & \text { (Tamil } \\
\text { Nadu) }\end{array}$ & $\begin{array}{l}\text { Female } \\
71 \% \\
\text { Male 29\% }\end{array}$ & 35 & 2.7 years & N.A. & $\begin{array}{l}\text { Annual } \\
\text { family } \\
\text { income } \\
\$ 420 ; 71 \% \\
\text { below } \\
\text { poverty } \\
\text { line }\end{array}$ \\
\hline India (Punjab) & Male & $18-30$ & N.A. & Laborer & N.A. \\
\hline Philippines & Male & 29 & 7 years & N.A. & $\begin{array}{l}\text { Annual } \\
\text { family } \\
\text { income } \\
\$ 480\end{array}$ \\
\hline Nigeria & Female & $\begin{array}{l}\text { Not } \\
\text { Available } \\
\text { (N.A.) }\end{array}$ & N.A. & N.A. & $\begin{array}{l}\text { Very low } \\
\text { annual } \\
\text { income }\end{array}$ \\
\hline Moldova & Male & $18-28$ & Poor & Laborer & Low \\
\hline
\end{tabular}

\section{III.4. Consent, Deception, Coercion, and Exploitation in the Procurement of Body Parts}

Organs are obtained through means varying from coercion and deception to fraudulently-obtained consent. Persons can be kidnapped, sold or killed for their organs. The United Nations has reported that child trafficking for organ harvesting has occurred and that "many abducted or missing children have subsequently been found dead, their bodies mutilated and certain organs removed". ${ }^{38}$ This practice has been associated with the African traditional practice of voodoo in which certain body parts are sold and used by practitioners to increase fertility, health, wealth or influence of a paying client. ${ }^{39}$

Organ donors have been coerced into selling body parts. After leaving their homes, itinerant workers who have been promised jobs that fail to materialise, are locked in safe houses until they are a match for a kidney recipient. The donor is then forced to relinquish an organ if he or she hopes to return home. ${ }^{40}$ The police in the Philippines

35 Council of Europe 2003, supra nt. 16.

36 Scheper-Hughes 2004, supra nt. 28.

37 Data for this table appeared in a different version in Aronowitz 2009, supra, nt. 19 and was compiled from the following sources: Scheper-Hughes, N., Commodifying Bodies, SAGE Publications LTD, London, 2003, Scheper-Hughes 2005, supra, nt. 29, Goyal et al. 2002, supra, nt. 33, GTZ GmbH 2004, supra, nt. 34, and the Council of Europe 2003, supra, nt. 16.

38 United Nations Office on Drugs and Crime, REPORT: Report of the Secretary-General to the Commission on Crime Prevention and Criminal Justice on preventing, combating and punishing trafficking in human organs, 21 February 2006, E/CN.15/2206/10, 2006, par. 82, available online at <unodc.org/unodc/en/commissions/CCPCJ/session/15.html> (accessed 03 October 2013).

39 Centre for African Studies, Scheper-Hughes, N., Bodies of Apartheid: the Ethics and Economics of Organ Transplantation in South Africa, 28 September 1999, available online at <sunsite.berkeley.edu/biotech/organswatch/pages/bodiesapart.html> (accessed 28 September 2013).

40 Aronowitz, 2009, supra, nt. 19. 
raided a house near Manila and freed nine men who were being held by a gang that had lured them with the promise of good jobs. Instead, they forced them to agree to "donate" a kidney. ${ }^{41}$

Fraudulent practices have also been documented. Cases of persons admitted into the hospital in Brazil, India and Argentina, for an unrelated illness or accident have reportedly had a kidney removed without their consent. ${ }^{42}$ One patient was admitted to a Sao Paulo (Brazil) hospital in June 1997 to have an ovarian cyst removed. During a routine follow-up examination, the woman's family doctor discovered that she was missing a kidney. The hospital later told the patient that her "missing kidney was embedded in the large 'mass' that had accumulated around her ovarian cyst" and that the diseased ovary and the kidney had been discarded. However, the hospital was unable to produce medical records. ${ }^{43}$ A leading expert on organ trafficking documented an asylum for mentally ill persons in Argentina in which the director exploited his patients by providing "blood, corneas and kidneys" to area hospitals. ${ }^{44}$

Another method of obtaining an organ is through deception or fraud. Donors are often illiterate or ignorant about health and medical issues. Cases have been documented whereby donors were told that if they donate a kidney, another will grow back to replace it. ${ }^{45}$ Another donor was told that only one kidney works while the other one sleeps and that the doctor would remove his "sleepy" kidney and leave him with the good one. ${ }^{46}$ The most common form of trafficking in organs, however, involves cases in which the recipient agrees to the sale. ${ }^{47}$ While donors may initially consent to selling a kidney, buyers exploit their ignorance, desperation, poverty or position of dependency or vulnerability. A mentally deficient criminal selling a kidney to his lawyer or a maid providing a kidney to her employer are examples of positions of dependency or vulnerability which may negate the consent of a person willing to donate an organ. ${ }^{48}$

Why is it human trafficking when donors often agree to voluntarily sell their organs? Deceit concerning payment and the medical risks involved in the operation often occurs so that donors are unable to make an informed decision. Exploitation extends beyond the mere fact that donors are not adequately advised of the risks or compensated for the loss of a kidney. Victims of organ trafficking may be promised complete post-operative medical care, but this rarely happens. ${ }^{49}$ Organs Watch, ${ }^{50}$

41 Medical News Today, Paddock, C., Philippine Government Bans Organ Transplants For Foreigners, May 1, 2008, available online at <medicalnewstoday.com/articles/105980.php $>$ (accessed 28 September 2013).

42 GTZ GmbH, 2004, supra, nt. 34.

43 Scheper-Hughes, N., "Commodity Fetishisms in Organ Trafficking", Body and Science, vol. 7, ed. 23, 2001, 31-62.

44 Scheper-Hughes 2003, supra, nt. 37.

45 Interview with Dr. Meena Poudel, Anti-Trafficking, Gender and Violence Against Women Advisor, USAID, Kathmandu, Nepal, April 25, 2013 and Ms. Shareen Tuladhar, Program Officer, CombatTrafficking in Persons, Asia Foundation, Kathmandu, Nepal, May 1, 2013.

46 Lip Magazine, Scheper-Hughes, N., Black Market Organs: Inside the Trans-Atlantic Transplant Tourism Trade, 3 June 2005, available online at <lipmagazine.org/articles/featscheperhughes.htm> (accessed 28 September 2013).

47 GTZ GmbH, 2004, supra, nt. 34.

48 Aronowitz 2009, supra, nt. 19. The man who received a kidney from his Filipino domestic worker justified this "donation" using the argument that "Filipinos are a people who are anxious to please their bosses" (Scheper-Hughes, N., "Keeping an eye on the global traffic in human organs", The Lancet, vol. 361, May 10, 2003, 1645-1648).

49 Aronowitz 2009, supra, nt. 19.

50 Organs Watch is a human rights oriented documentation center at the University of California, Berkeley, which investigates complaints, conducts research and issues reports on the global trade in organs. 
which carried out research on organ trafficking in countries around the world, found that none of the donors interviewed in Brazil, Manila, Moldova and Turkey had been treated by a doctor a year after the operation, despite frequent complaints of weakness and pain. Some had even been turned away from the same hospitals which had performed the surgery. In one case a kidney seller was given a prescription medicine for the pain, but was unable to pay for the prescription of painkillers and antibiotics. Others interviewed also reported being fearful of not being able to pay for medication if they needed it. ${ }^{51}$

\section{III.5. The Harm to Organ Donors: Economic, Physical and Psychological Consequences}

Studies on those who have been trafficked for their organs, including those who have willingly sold their organs, show that the quality of the life of these patients is not better off than it was prior to the operation. The consequences can be dire, manifesting themselves in economical, physical and psychological hardships.

In a study of 305 Indians who had sold a kidney in Chennai, India, an average of six years before the survey, doctors found that $96 \%$ of the sellers had sold their kidney to escape debt. On average, the sellers received $\$ 1,070$ which was spent on food and clothing, and repaying debts. Due to the weakened condition of the donor, the average family income declined after the operation, families were still in debt and the number who now lived below the poverty line had increased. ${ }^{52}$ Further studies on kidney sellers in Iran, India, Moldova and the Philippines indicate that they experience unemployment, reduced income and economic hardship. Unable to sustain the heavy demands placed upon them after the operation, workers previously involved in agriculture or construction work found themselves unemployed. ${ }^{53}$ In Moldova, kidney sellers reported having to spend their earnings to hire labourers to compensate for the heavy agricultural work they could not do. ${ }^{54}$

Victims are exposed to serious consequences to their health either during or after the operation. Police in the Philippines raided apartments and found surgical operations were being carried out to remove kidneys under poor hygienic conditions. Persons have reportedly died under such circumstances. ${ }^{55}$ Without proper postoperative care, the physical health of kidney sellers often deteriorates after the operation; patients complain of chronic pain, weakness and ill-health. This was reported in $86 \%$ of the patients interviewed in India. ${ }^{56}$ Donors in the Philippines and Eastern European countries reportedly suffered from hypertension and kidney insufficiency. In many of the cases investigated, few of the donors in Turkey, Moldova, the Philippines or Brazil had seen a doctor or received post-operative health care - a year after the operation. Patients were either unable to pay for the services or refused medical care. ${ }^{57}$ Deceived donors are unable to report their victimisation to police as they are often participating in the illegal act of selling an organ. Police in Punjab, India reported that donors were not provided proper post-operative care, were thrown out of the hospital one week after the surgery and threatened with imprisonment for participating in illegal organ transplants. Six persons died as a result

\footnotetext{
Scheper-Hughers 2003, supra, nt. 37.

Goyal et al. 2002, supra, nt. 33.

Aronowitz 2009, supra, nt. 19.

54 Scheper-Hughers 2003, supra, nt. 37.

55 Paddock 2008, supra, nt. 41.

56 Goyal et al. 2002, supra, nt. 33.

57 Scheper-Hughes 2003, supra, nt. 37.
} 
of the transplants. ${ }^{58}$ Health authorities in the Philippines report that due to lack of postoperative treatment for poor patients, many donors develop health problems such as high blood pressure and urinary tract infections. ${ }^{59}$

Donors also suffer psychologically as a consequence of the transplant. Reports of a sense of worthlessness, serious depression, social isolation and family problems are not uncommon. ${ }^{60}$ In Moldova, sellers are excommunicated from the local Orthodox Church, their chances of marriage are non-existent and many are alienated from their families. There are reports of kidney sellers disappearing from their families and one committed suicide. Fear of being labelled disabled or weak results in male kidney donors from seeking follow-up medical care. ${ }^{61}$

\section{III.6. Individuals and Organizations Involved in Organ Trafficking}

This crime, unlike other forms of trafficking, cannot take place without the complicity of professional medical staff operating in hospitals or private clinics. These doctors knowingly remove healthy organs from individuals not related to the recipients and often in countries where organ donation between unrelated persons is a violation of criminal law - a topic covered later in this paper. In addition to the donor and seller, there are a number of brokers and agents involved. These have been identified as, but are not limited to, hospital and medical staff, nephrologists, postoperative nurses, medical directors of transplant units, dual surgical teams working in tandem, travel agents and tour operators to organize travel, passports and visas. Perhaps the most important link between donor and recipient in the organ trade is the organ hunters or brokers - those who recruit 'donors' locally or internationally from among vulnerable and marginalized populations. ${ }^{62}$ These often unscrupulous individuals have no link to the medical field and are reported to be recruited from army barracks, bars, jails and prisons, unemployment offices and shopping malls. ${ }^{63}$ Organ brokers scour slum areas in poor countries looking for suitable donors.

A huge organ trafficking operation in India between 1997 and 2002 is estimated to have generated a $\$ 31.4$ million dollars exchange between the donors, middlemen and doctors. While the recipients were charged between $\$ 104,600$ and $\$ 209,200$, the organ sellers, poor migrant labourers from Bihar and Uttar Pradesh states were paid between $\$ 525$ and $\$ 1,050 . .^{64}$

The internet provides a forum for organ donor and recipient to "meet" and could actually replace the organ broker. Dubious websites such as "www.Liver4You.org" used to advertise to those looking to purchase a new kidney for a mere $\$ 85,000$ to $\$ 115,000 .{ }^{65}$ The organ seller often receives no more than a few thousand dollars of this fee. Other advertisements on the internet encourage people to sell a kidney to get out

58 Kumar, S., "Police uncover large scale organ trafficking in Punjab", British Medical Journal, vol. 326, 2003, 180.

59 Paddock 2008, supra, nt. 41.

60 Interview with Dr. Meena Poudel, Anti-Trafficking, Trafficking, Gender and Violence Against Women Advisor, USAID, April 25, 2013 and Ms. Shareen Tuladhar, Program Officer, CombatTrafficking in Persons, Asia Foundation, May 1, 2013.

${ }^{61}$ Scheper-Hughes, N., "Keeping an eye on the global traffic in human organs", The Lancet, vol. 361, 2003, 1645-1648, and Scheper-Hughes 2003, supra, nt. 37.

62 UN Global Initiative to Fight Human Trafficking (UN.GIFT), 006 Workshop: Criminal Justice Responses to Human Trafficking, 13-15 February 2008, available online at <www.ungift.org/docs/ungift/pdf/vf/backgroundpapers/BP006CriminalJusticeResponses.pdf> (accessed 03 October 2013).

63 Scheper-Hughes 2004, supra, nt. 28.

64 Kumar 2003, supra, nt. 58.

65 Information available online at <www.liver4you.org> (Accessed 17 June 2008). 
of debt: "Crisis? Crisis is running over the planet, but you've got a chance! The cost of a human kidney is $\$ 70-80 \mathrm{~K}$ and it could be enough to pay all your debts, credits and much more. You can help yourself right now: just sell your kidney. Hurry up!"66

According to the United Nations, corruption is an integral element in organ trafficking and transplantation. ${ }^{67}$ It may be as "benign" as allowing wealthy patients to climb to the top of waiting lists for organ transplants, or may be as insidious as protecting illicit practices. ${ }^{68} \mathrm{~A}$ large scale organ trafficking operation uncovered by the Indian Government involved 500 patients, three hospitals, ten pathology clinics, five diagnostic centres, twenty paramedics, five nurses and four doctors. Police were also implicated in the mala fide practice. ${ }^{69}$

The organ trafficking trade involves abuses of human rights, deception and at times criminal practices in the abduction or false imprisonment of those being held captive until there is a match to a recipient. The legal and medical communities are at odds concerning the best measures to address this problem. The following section examines legal measures in place to address the donation and sale of organs and explores solutions to end the practice of organ trafficking.

\section{Legal Instruments Dealing with Organ Trafficking}

\section{IV.1. Binding Instruments}

\section{IV.1.1. International Instruments}

Putting the responsibility of combating the crime of organ trafficking, and of human trafficking in general, in the hands of individual states ignores the transnational nature of trafficking. Therefore, it is important to consider the establishment of international legal initiatives to ensure cooperation between State parties and the international criminalization of organ trafficking. To date, there are no legally binding international instruments devoted to organ trafficking alone. ${ }^{70}$ There are several international documents, however, which deal with medicine, health sector and/or human trafficking in general and incorporate the crime of organ trafficking therein. The most important binding international legal document considering human trafficking with the purpose of the removal of organs is the United Nations Protocol to Prevent, Suppress and Punish Trafficking in Persons, Especially Women and Children, ${ }^{71}$ supplementing the United Nations Convention against Transnational Organized Crime. $^{72}$ The Protocol is directed at human trafficking in general but includes trafficking with the purpose of the removal of organs within the scope of its definition.

66 If you act before August $1^{\text {st }}$ and recruit a friend, you can get $20 \%$ of the price of your friend's kidney. (Information at Complete Health Care Lifeline at < kidneykidney.com> (accessed 5 June 2013).

67 United Nations Office on Drugs and Crime, Trafficking in Persons, Global Patterns, April 2006, available online at <www.unodc.org/pdf/traffickinginpersons_report_2006-04.pdf> (accessed 03 October 2013).

68 Aronowitz 2009, supra, nt. 19.

69 Gentleman, A., "Kidney Thefts Shock India", New York Times, 30 January 2008, available online at <nytimes.com/2008/01/30/world/asia/30kidney.html> (accessed 03 October 2013).

70 Parliamentary Assembly of the Council of Europe, Towards a Council of Europe convention to combat trafficking in organs, tissues and cells of human origin, 20 December 2012, available online at <assembly.coe.int/ASP/XRef/X2H-DW-XSL.asp?fileid=19236\&lang=en> (accessed 03 October 2013).

71 Protocol to Prevent, Suppress and Punish Trafficking in Persons, Especially Women and Children, supplementing the United Nations Convention against Transnational Organised Crime (Palermo Protocol), 2000, 2237 UNTS 319.

72 The Convention may also be referred to as the 'Organized Crime Convention'. 
The Protocol specifies that ratification requires the criminalisation, prohibition and punishment of the act of trafficking and adopting legislation to ensure this ${ }^{73}$ providing assistance and protection for and aid in repatriation of victims of trafficking, ${ }^{74}$ and facilitating the establishment of prevention programs for trafficking, the establishment of effective information exchange and training for law enforcement professionals, and measures concerning border control and the security and validity of travel documentation..$^{75}$ The Protocol has been signed by 117 and ratified by 158 UN Member States. ${ }^{76}$

\section{IV.1.2. Regional instruments}

The most recent regional binding instrument dealing with the issue of human trafficking in general, and incorporating the crime of organ trafficking specifically is the 2008 Council of Europe (CoE) Convention on Action against Trafficking in Human Beings. The Convention adheres to the definition of trafficking as put forward by the UN Trafficking in Persons Protocol. Being a CoE initiative, the Convention focuses mainly on inter-European cooperation and the prevention of trafficking in persons.

Another notable example of a regional legally binding document incorporating trafficking in organs is the 1997 Council of Europe Convention on Human Rights and Biomedicine, with its supplementary protocol dating from 2002, the Additional Protocol to the Convention on Human Rights and Biomedicine concerning Transplantation of Organs and Tissues of Human Origin. Most notably, Article 22 of the supplementary Protocol states that "Organ and tissue trafficking shall be prohibited". The requirements for ratification of the Convention and sanctions for the infringement of provisions for Parties put forward by the Convention are further specified in Articles 23 through 25. These include providing "appropriate judicial protection to prevent or to put a stop to the unlawful infringement of the rights and principles set forth in the Convention", ${ }^{77}$ providing persons who have "suffered undue damage resulting from an intervention" with compensations according to the "conditions and procedures prescribed by law", ${ }^{78}$ and the provision of "appropriate sanctions to be applied in the event of infringement of the provisions" by the Parties. ${ }^{79}$

In addition to this Convention, the Council of Europe is currently working on the adoption of the $\mathrm{CoE}$ Convention against Trafficking in Human Organs, thereby affirming the need for an international legal document dealing specifically with the issue of organ trafficking. Hence, the $\mathrm{CoE}$ will be the first legally binding international instrument dealing solely with the issue of organ trafficking. ${ }^{80}$ The document is still pending before the Committee of Ministers and shall include provisions on the measures for the prevention of organ trafficking, protection of victims of the crime and national and international cooperation against organ trafficking and transplant tourism. $^{81}$

73 As specified under Art. 5.

74 Idem, Art. 6 and 8.

75 Idem, Art. 9 and 13.

76 Idem, Chapter XVII Penal Matters, sub 12 a.

77 Council of Europe, Convention for the Protection of Human Rights and Dignity of the Human Being with regard to the Applications of Biology and Medicine: Convention on Human Rights and Biomedicine, 1997, Oviedo, 4 IV, Art. 23.

78 Idem, Art. 24.

79 Idem, Art. 25.

80 Council of Europe 2012, supra, nt. 70.

81 Ibid. 


\section{IV.1.3. Domestic legislation}

In general, the prohibition of organ trafficking and the punishment thereof is governed by domestic legislation. A number of governments have experimented with legislation prohibiting the sale of organs. ${ }^{82}$ For the purpose of this article, the Netherlands will be used as a case study to highlight the workings of domestic legislation on organ trafficking. Human trafficking for the purpose of organ removal is included under Article 273f of the Dutch Criminal Code (DCC). Article 273f deals with the crime of human trafficking in general and organ trafficking was included within the scope of the article in 2005. The article specifies the criminalisation of organ trafficking and further states that a Dutch national who is guilty of organ trafficking abroad is also punishable under article 273f DCC. The liability to criminal prosecution of Dutch citizens who commit their crime elsewhere has been included within the scope of article 273f DCC since the implementation of the EU Directive on preventing and combating trafficking in human beings and protecting its victims $(2011 / 36 / \mathrm{EU}) .^{83}$ Article 10 of the EU Directive further expands on the issue of extra-territorial jurisdiction and provides Member States with the option to establish jurisdiction over offenses for the benefit of legal persons established in the territory of the Member State and over offences committed for the benefit of a permanent resident of the territory of that Member State as well as offences committed against nationals or permanent residents. ${ }^{84}$

Voluntary organ donations in the Netherlands are regulated by the Organ Donation Act. The Act specifies the most important conditions for the donation of organs as explicit, informed consent by the donor (Article 8), and that no payment can be procured for the removal of the organ (Article 2). ${ }^{85}$ The Organ Donation Act specifies that the intentional removal of an organ from a living person or after a person's death without prior consent constitutes a criminal offense, as well as deliberately causing or encouraging a person to provide permission to remove an organ during his or her lifetime in return for a financial payment that amounts to more than the costs incurred by the donor as a direct result of the organ removal operation. ${ }^{86}$

Furthermore, two important legal amendments have been made in the Netherlands to further minimise the participation of Dutch nationals in organ trafficking related practices. Firstly, an amendment has been made to the Dutch Health Insurance Act, which previously stated that transplants completed abroad should be paid for by health insurers regardless of whether or not the organ had been purchased. Article 2.4 (1) (c) has now been amended to provide that the costs of transplants conducted outside of the European Union (EU) and parties to the Agreement on the European Economic Area (EEA) will not be reimbursed unless it can be effectively proven that the organ is

82 In the United Kingdom, for instance, the 'Human Organ Transplants Act 1989' prohibits commercial transactions in human organs and establishes general guidelines, such as placing restriction on the transplantation of organs between persons who are not genetically related (The Human Organ Transplant Act 1989 (Chapter 31)). India, too, has legislation. The 1994 'Transplantation of Human Organs Act' prohibits commercial dealings in human organs and restricts live donations to relatives.

83 Art. 10, para.1, subsection b of the Directive 2011/36/EU of the European Parliament and of the Council of 5 April 2011 on preventing and combating trafficking in human beings and protecting its victims, and replacing Council Framework Decision 2002/629/JHA.

84 Idem, para. 2.

85 National Rapporteur on Trafficking in Human Beings (2012). Human Trafficking for the purpose of the removal of organs and forced commercial surrogacy. The Hague: BNRM, p. 5.

86 Ibid. 
donated by a spouse, a registered partner or a blood relative of the insured person. ${ }^{87}$ However, for organ transplants conducted within the European Union and parties to the Agreement on the European Economic Area, it is not a requirement for health insurance companies to refuse to pay, even in the case of a reasonable or serious doubt about the contextual factors of transplants; in those cases, reimbursement is determined by the terms of policy of the insurance companies. ${ }^{88}$ Secondly, in June 2009 the Subsidy Scheme for donation during life entered into force in the Netherlands; the Scheme ensures that donors receive compensation for expenses incurred through the donation and which are not reimbursed in any other way, thereby giving the compensation of expenses for donors a more permanent character, anchoring it more firmly in Dutch public law and decreasing potential obstacles for organ donation during life. ${ }^{89}$

\section{IV.2. Non-binding international instruments}

Several non-binding international instruments have been put forward condemning the practice of international organ trafficking as well as providing the international community with recommendations for eradicating the crime. The World Health Organization (WHO) has established a set of guiding principles $^{90}$ governing the practice of organ transplantation in general and, more specifically, condemning the commercial sale of organs. ${ }^{91}$ As Guiding Principle 5 of the WHO Guidelines states: "Cells, tissues and organs should only be donated freely, without any monetary payment or other reward of monetary value. Purchasing, or offering to purchase, cells, tissues or organs for transplantation, or their sale by living persons or by the next of kin for deceased persons, should be banned." Also: "The prohibition on sale or purchase of cells, tissues and organs does not preclude reimbursing reasonable and verifiable expenses incurred by the donor, including loss of income, or paying the costs of recovering, processing, preserving and supplying human cells, tissues or organs for transplantation". The Principles further put forward that "the organization and execution of donation and transplantation activities, as well as their clinical results, must be transparent and open to scrutiny, while ensuring that the personal anonymity and privacy of donors and recipients are always protected". ${ }^{22}$ This Principle condemns the practice of the illicit involvement of medical health care professionals in obscure and questionable organ transplantation activities. Moreover, Resolution WHA63.22, adopted by the $63^{\text {rd }}$ World Health Assembly in May 2010, endorses a revision of the WHO Guiding Principles and further urges Member States to implement the Guiding Principles, to promote increased altruistic donation, to establish transparent systems for the allocation of organs and tissues, and to promote the collection of data relating to organ trafficking. ${ }^{93}$

87 Ibid.

88 Ibid.

89 Ibid.

90 The WHO Guiding Principles on Human Cell, Tissue and Organ Transplantation, available at: $<$ who.int/transplantation/Guiding_PrinciplesTransplantation_WHA63.22en.pdf> (accessed June 26th, 2013).

91 Idem, Guiding Principle 5.

92 Idem, Guiding Principle 11.

93 World Health Assembly, Sixty-Third Session, Eighth plenary meeting, 21 May 2010, nr. A63/VR/8, available online at <who.int/gb/ebwha/pdf_files/WHA63/A63_R22-en.pdf> (accessed 14 October 2013). 
In addition to the Guiding Principles, the WHO published the Global Glossary of Terms and Definitions on Donation and Transplantation in 2009.94 The Global Glossary was established in response to a need for internationally recognized definitions and terminology with respect to organ donation and transplantation and urges for the uniformity of data and information for the Global Database on Donation and Transplantation. ${ }^{95}$ According to the WHO, the Glossary aims to "clarify communication in the area of donation and transplantation, whether for the lay public or for technical, clinical, legal or ethical purposes."96 The Glossary includes existing official definitions as well as newly added definitions and terms. ${ }^{97}$

A remarkable effort has been made on the part of several medical associations to establish international consensus condemning the practice of organ trafficking. Cooperation of the Transplantation Society and the International Society of Nephrology led to the establishment of the Declaration of Istanbul in 2008. The Declaration defines organ trafficking, transplant tourism and commercialism and seeks to achieve consensus regarding the principles of practice and the recommendation of alternatives which address the shortage of human organs, as well as the establishment of professional transplantation guidelines, ${ }^{98}$ and signals an effort towards collaboration within the international medical community. ${ }^{99}$ The Declaration calls for a reduction of the burden on live donors by increasing organ donation from cadaver donors and urges States to adapt their legislation in order to foster the use of cadaver donations. ${ }^{100}$

\section{IV.3. Gaps and flaws in current legislation}

A joint study conducted by the UN and the Council of Europe ${ }^{101}$ concluded that while there are international instruments which cover all relevant aspects of the prevention and combatting of organ trafficking, ${ }^{102}$ these instruments have failed to significantly reduce organ trafficking. The study determined that one of the prime conditions for such international legal instruments to work is the generation of stronger political will on the part of Member States to implement organ-removal provisions. ${ }^{103}$ Similarly, the study recognizes that the definition of human trafficking, including trafficking for the purpose of organ removal, is not the same across countries and urges the

94 WHO Global Glossary of Terms and Definitions on Donation and Transplantation, available online at <who.int/transplantation/activities/GlobalGlossaryonDonationTransplantation.pdf> (accessed 4 July 2013).

95 Ibid.

96 Idem, 1.

97 Ibid.

98 Declarationofistanbul.org, "The history and development of the Declaration of Istanbul", available online

$<$ declarationofistanbul.org/index.php?option=com_content\&view=article $\&$ id $=77 \&$ Itemid=57> (accessed 14 October 2013).

99 Ibid.

100 Idem, Declaration of Istanbul, Proposals, under "To respond to the need to increase deceased donation", 1-4.

101 Joint Council of Europe/United Nations Study, "Trafficking in organs, tissues and cells and trafficking in human beings for the purpose of the removal of organs", Directorate General of Human Rights and Legal Affairs Council of Europe, 2009, available online at $<$ coe.int/t/dghl/monitoring/trafficking/docs/news/organtrafficking_study.pdf> (accessed 5 July 2013).

102 Most notably the UN Trafficking in Persons Protocol and the Council of Europe Anti-Trafficking Convention.

103 Idem, 97. 
establishment of more international consensus concerning the topic and an increase in cooperation to diminish the crime. ${ }^{104}$

The UN Trafficking in Persons Protocol was the first binding instrument dealing with organ trafficking and, thus, it has had an anchoring effect on subsequent treaties and legislation and yet has received a significant amount of criticism from commentators. ${ }^{105}$ Criticism has ranged from a lack of Member State implementation and compliance, to design flaws inherent to the Protocol. ${ }^{106}$ The design flaws are related to the wording and language used within the document. ${ }^{107}$ The Trafficking in Persons Protocol aims to combat and eradicate human trafficking through a combination of criminalization, prevention and victim assistance, yet parties have primarily focused upon the element of criminalization. ${ }^{108}$ Moreover, as its supplementation to the U.N. Convention demonstrates as well as the numerous referencing within the document to 'organized criminal groups' and 'transnational criminal organizations', the Protocol places a heavy emphasis on the relationship between organised crime and trafficking. Whereas there is indeed a strong connection between organised crime and human trafficking, ${ }^{109}$ organised crime is not the sole cause of trafficking. ${ }^{110}$

Critics have claimed that the Protocol's emphasis upon organised crime has caused states to ignore intrastate trafficking as well as confusing national policies, which have been set up to combat organised crime and trafficking simultaneously; this has led to restrictive and narrow-minded policy-making in which there often is no differentiation between trafficking and smuggling, consequently leading countries to incorrectly deport or prosecute victims. ${ }^{111}$ Moreover, with its emphasis on prosecution and criminalization, the Protocol fails to recognise and address the underlying socioeconomic factors driving human trafficking, ${ }^{112}$ meaning that even where offenders are prosecuted, the lack of change in the socioeconomic conditions for victims leaves them vulnerable to subsequent abuse and victimisation. Considering the anchoring effect of the Protocol and the nature of the binding legal instruments discussed previously, many, if not all, current binding instruments share the feature of emphasis upon prosecution and criminalization with the Protocol. Similarly, the Council of Europe (CoE) Convention on Action against Trafficking in Human Beings as well as other non-specific legal instruments focus upon the element of criminalisation and prohibition of (organ) trafficking. Whereas victim support and assistance as well as the establishment of prevention programs are included within the scope of these instruments, they largely focus on post-hoc remedies and neglect the differentiation between human trafficking for the purpose of organ removal and other forms of human trafficking, which is essential in attempting to tackle the problem.

Concerning domestic legislation, there is often a lack of knowledge or political will to enforce the law. While domestic laws may prohibit a country's citizens from purchasing or selling an organ on the black market, they do nothing to address the

\footnotetext{
104 Ibid.

105 Kelly, E., "International Organ Trafficking Crisis: Solutions Addressing the Heart of the Matter", Boston College Law Review, vol. 54, ed. 3, 2013, 1339.

106 Ibid.

107 Ibid.

108 Ibid.

109 Surtees, R., "Traffickers and Trafficking in Southern and Eastern Europe: Considering the Other Side of Human Trafficking", European Journal of Criminology, vol. 5, ed. 1, 2008, 39-68.

110 Kelly 2013, supra, nt. 105, 1339.

111 Ibid.

112 Idem, 1340.
} 
displacement effect that occurs or the problems of organ shortages. ${ }^{113}$ Addressing the organ trade requires both a legal and an extra-legal approach. The legal amendments made in the Netherlands, discussed in paragraph IV.1.3 of this article, arguably do take on a more problem-driven approach as they do not solely focus upon criminalization. Specifically, the amendment made to the Health Insurance Act recognizes the nature of transplant tourism. While Article 2.4(1) (c) ensures that insurers no longer reimburse transplants conducted with non-next of kin donors outside the EU and the EEA, it does little to alleviate the problem for victims or tackle the social and economic factors driving organ trafficking. The introduction of the Subsidy Scheme focuses more upon the underlying societal issues; it aims to increase organ donation during life, thereby hopefully decreasing the demand for organs from trafficked persons from abroad.

\section{Recommendations: towards a more problem-driven solution}

The problem is a complex one which needs to be addressed from legal, medical and ethical perspectives. Given its often transnational nature, the ease and affordability of international travel and the possibility that the internet can easily be used to recruit new donors, both legal and extra-legal measures must be taken to reign in this illicit and exploitive trade. From a legal perspective, it is likely that the establishment of an international binding legal instrument which, instead of adopting a criminal law framework, is more victim-focused and emphasises removing the causes of organ trafficking would be more effective in eradicating the crime. ${ }^{114}$ In order to tackle the causes, the factors underlying the organ trafficking market must be examined and targeted. Inherent to the market for trafficked organs is the demand for organs. As such, measures must be taken to meet the demand for organs in other ways. Instead of taking an approach which is predominantly criminal law-focused, and thus post-hoc, in nature, States can and should take all actors involved in the process of organ trafficking into account in order to reduce the demand for trafficked organs. ${ }^{115}$ In addition to government officials, offenders and victims, the facilitators in the process must also be taken into account: members of the medical and health care community, health insurers, tour operators and community leaders can all be seen as important actors within the issue of human trafficking for the purpose of organ removal. For instance, it has been noted that health insurance companies preferentially support illegal practices in some countries. ${ }^{116}$ According to the United Nations Office on Drugs and Crime, the following conditions are fundamental in decreasing the demand for organs: "The need to (1) reduce the health conditions which lead to organ failure; (2) Increase the supply of organs donated through channels which guard against exploitation of donors who are willing and able to donate their organs." 117

Two approaches to meet the demand can be taken. In order to foster an increase of the supply of organs through regulated or legal channels, the establishment of an

\footnotetext{
113 When India's Transplantation of Human Organs Act went into effect in 1994, Malaysian transplant patients immediately found a new destination in China, Shimazono, Y., Public Health Reviews The state of the international organ trade: a provisional picture based on integration of available information, Bulletin of the World Health Organization, vol. 85, ed. 12, 2007, 955-961.

114 Kelly 2013, supra, nt. 105, 1339.

115 UNODC 2008, supra, nt. 7, 532.

116 Budiani-Saberi \& Delmonico 2008, supra, nt. 11, 928.

117 UNODC 2008, supra, nt. 7, 532.
} 
effective system of cadaver organ donation in each country is essential. ${ }^{118}$ One way in which this could be done is by implementing a "presumed consent" or "opt out" system, meaning that a person is automatically presumed to be an organ donor upon death unless the person specifies that he or she refuses to be a donor (this or similar systems are in place in Austria, Belgium, France, Hungary, Poland, Portugal and Sweden). In 2003, in countries in which the presumed consent system or opt-out system was in place, the vast majority of the population expressed effective consent. This varied from a low of $85,9 \%$ in Sweden to $99,98 \%$ in Austria. By contrast, in explicit consent or opt-in countries, the percentage of organ donors is much lower. Only $4,25 \%$ of the population in Denmark, $12 \%$ in Germany, $17,2 \%$ in the UK and $27,5 \%$ of the population in the Netherlands are organ donors. ${ }^{119}$ Organizations (such as the Multi Organ Harvesting Aid Network Foundation (MOHAN)) can provide predeath counseling to family members which could increase the donation of cadaver organs. ${ }^{120}$ The second approach involves transparency and regulating the system using live donors so that impoverished donors can provide their organs in exchange for money, but at the same time are aware of their rights and receive excellent postoperative care. ${ }^{121}$

Only a multi-tiered and broad approach can ensure the successful prevention and eradication of the illicit organ trade. It is essential that if domestic laws exist, there is political will and adequate awareness of the law to ensure its enforcement. Countries which have proposed a ban upon the buying and selling of organs should not permit their nationals to travel to destination countries to procure organs which may have been obtained as a result of human trafficking, after which they return to their home countries to acquire insured health care. ${ }^{122}$ Above all, the human rights and health of the most vulnerable members of society must be protected. This can be done through pre-emptive legal measures, effective self-regulation by the medical community, increased awareness and the establishment of measures to ensure an increase in cadaver donations.

www.grojil.org

118 Budiani-Saberi \& Delmonico 2008, supra, nt. 11, 928.

119 Johnson, E.J., and Goldstein, D.G. "Do defaults save lives?" Science, vol. 302, ed. 5649, 1338-1339.

120 GTZ GmbH 2004, supra, nt. 34.

${ }^{121}$ Scheper-Hughes 2004, supra, nt. 29.

${ }^{122}$ Ibid. 